\title{
Topographic relationship between maxillary sinus and roots of posterior teeth: a cone beam tomographic analysis
}

\section{Purpose}

The objective of the research was to determine the relationship between root apices and maxillary sinus wall, and to analyze pulpoapical conditions of $2^{\text {nd }}$ premolars, $1^{\text {st }}$ molars, $2^{\text {nd }}$ molars, $3^{\text {rd }}$ molars using cone beam computerized tomography (CBCT).

\section{Materials and Methods}

This study was conducted on a retrospective manner of CBCT images of 1000 maxillary sinus with 500 subjects, who visited the Department of Dento-Maxillofacial Radiology. The association of each teeth with sinus floor and pulpoapical status were categorized. The association among gender, age, lateralization of sinus cavity were evaluated.

\section{Results}

A total of 602 second premolars, 500 first molars, 623 second molars, 347 third molars were evaluated. There were no significant differences between pulpoapical condition of teeth and gender or left and right sides $(p=0.065, p=0.072)$. There were significant associations between pulpoapical condition of all teeth and age $(p=0.023)$, and the relationship of each root with maxillary sinus and age $(p=0.037)$. There was significant association between vertical position and right/left sides in second and third molars $(\mathrm{p}=0.033)$.

\section{Conclusion}

Age seems to have relationship with periapical condition of teeth, and the association of root with the sinus cavity.

Keywords: Radiology, Age, Inflammation, Pulp, Root canal

\section{Introduction}

Maxillary sinuses are the largest cavities within the maxillary bone (1). The dimensions of the sinus shows variations (2). The sinus floor extends between adjacent teeth (3), mostly creating elevations in the sinus surface (4). Maxillary molar and premolar roots are in close association with the sinus floor and may cause undesirable oroantral communication (5, 6). Evaluating the anatomic relation between roots of posterior teeth and the cavity floor before planning root canal treatment and procedures related to root apices are important (5).

Close proximity between the root of the maxillary posterior teeth and sinus floor can induce infection from a periapical problem spreading within the sinus, $(3,7)$ and may cause sinus diseases (8). Previous studies reported that the anatomic association between tooth roots and maxillary sinus floor may affect the spread of odontogenic infection caused by molar teeth $(9,10)$. It is known that the relationship between tooth maxillary sinus is affected by orthodontic treatment, (11) including intrusion or bodily movement may cause moderate root resorption close relationship maxillary sinus (12). When dental roots are closely related to the maxil-

\author{
Tuba Talo Yildirim ${ }^{1}$ (D), \\ Faruk Oztekin² ${ }^{\mathbb{D}}$, \\ Melek Didem Tözüm ${ }^{3}$
}

ORCID IDs of the authors: T.T.Y. 0000-0002-7577-5703, F.Ö. 0000-0002-5131-0063; M.D.T. 0000-0002-5769-8468

\footnotetext{
${ }^{1}$ Department of Periodontology, Faculty of Dentistry, Firat University, Elazig, Turkey

${ }^{2}$ Department of Endodontic, Faculty of Dentistry, Firat University, Elazig, Turkey.

${ }^{3}$ Pre-Doctoral Clinics, College of Dentistry, University of Illinois at Chicago, Chicago, IL, U.S.A.

Corresponding Author: Tuba Talo Yildirim

E-mail: dt_talo@hotmail.com

Received: 6 May, 2020 Revised: 30 July, 2020 Accepted: 16 November, 2020 DOI: 10.26650/eor.20210052
} 
lary sinus, dental problems (i.e. periapical lesions), become a possible source of the inflammation directing the sinus cavity $(1,13)$. Therefore, clinicians should carefully examine the association between the root of posterior teeth and the maxillary sinus before dental intervention $(5,6)$.

Cone beam computerized tomography (CBCT) scans are very important to evaluate the characteristics of maxillary sinus including the association between maxillary teeth and sinus. Advanced scanning is a valuable clinical three-dimensional technique which has several advantages including better resolution and decreased scanning time $(14,15)$. CBCT seems to help the practitioners making more accurate evaluation of hard tissues, and helps decreasing the distortion and superimposition of the related anatomic landmark (16).

The objective of the this research was to understand the topographic association between the maxillary cavity and roots of posterior teeth by using CBCT imaging.

\section{Materials and Methods}

\section{Study samples}

Six hundred and twenty patients with 1240 sinus images were included in this study. The CBCT sections taken from individuals who referred the Department of Dentomaxillofacial Radiology, during the period of 2009 to 2012. Patients, who were looking for dental procedures (i.e. ebdoosseous implants, root canal procedures, periodontal application, dentofacial treatments and oral diseases) were included. All patients with total edentulism, pathologies related to roots, bone lesions in associations with systemic disorders, traumatic lesions, tumors in the maxilla premolar/molar region, reduced sinus visibility in the $\mathrm{CBCT}$ scan volume, or with evident artifacts, superposition and magnification were excluded from this study. Therefore, this retrospective study consisted of 716 maxillary sinuses of CBCT images achieved from 358 patients ( 160 female, 198 male patients and mean age of 36.66 \pm 13.51 years). Ethics committee approval was received (Approval number: 971328527050.01.04).

\section{CBCT measurements}

The CBCT sections were obtained from a scanner (I-CAT vision TM Imaging Science International, Hatfield, PA, USA) at $120 \mathrm{kVp}$ and $18.54 \mathrm{~mA}$, with an exposure time of 8-9 seconds. The voxel size of the images was $0.25 \mathrm{~mm}-0.4 \mathrm{~mm}$. Image measurements was done on the KaVo 3D eXam Vision (KaVo Dental GmbH, Biberach/Riss, Germany). All scans were evaluated by one calibrated examiner (T.T.Y.).

CBCT sections were reviewed twice by the same reserchers to reduce error. The amount of error on the average is 0.0027 , which is close to zero. Hence, we may suggest that the measurement error is negligible. We also provide intra-class correlation coefficient which is found to be high and acceptable as 0.82 .

\section{Evaluations of anatomic associations between the maxillary si-} nus and teeth

The sagittal images were used to detect the relationship between sinus floor and the roots of the maxillary premo- lars/molars, and classified into 5 classes as previously described (Figure 1) $(1,17)$ :

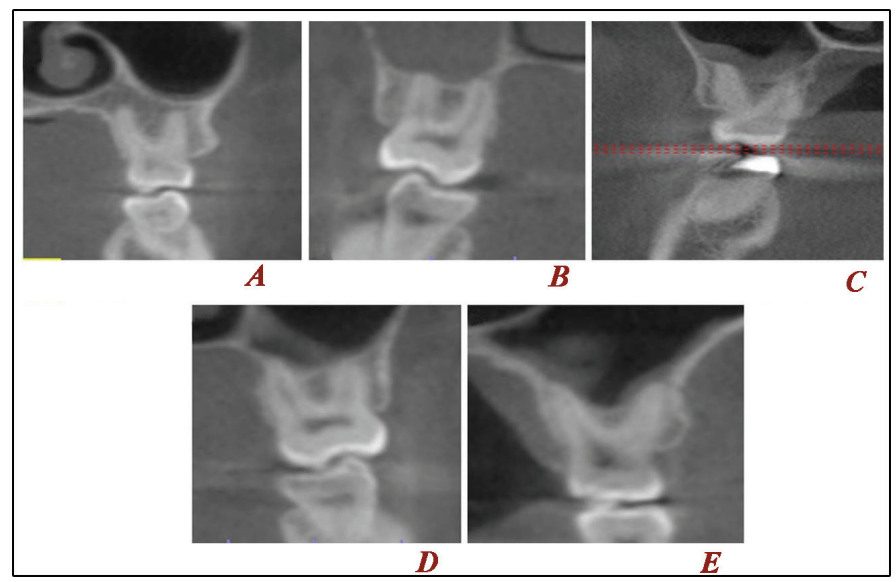

Figure 1. CBCT images show 5 types of vertical relationships between the roots of the maxillary premolars/molars and the sinus floor. A. Buccal and palatal roots apices were not in contact with the maxillary sinus floor, $B$. Buccal and palatal roots apices were in contact with the maxillary sinus floor, C. Buccal root apices were penetrated into the sinus cavity over the maxillary sinus floor, D. Palatal root apices were penetrated into the sinus cavity over the maxillary sinus floor, E. Buccal and palatal root apices were penetrated into the sinus cavity over maxillary sinus floor.

Class I: Buccal and palatal roots apex were not contact with the sinus floor,

Class II: Buccal and palatal roots apex were in contact with the sinus floor,

Class III: Buccal root apex were penetrated into the sinus cavity over the maxillary sinus floor,

Class IV: Palatal root apex were penetrated into the sinus cavity over the maxillary sinus floor,

Class V: Buccal and palatal root apex were penetrated into the sinus cavity over maxillary sinus floor.

\section{Assessment of pulpoapikal condition maxillary posteriors}

The pulpoapikal condition maxillary premolars and molars were classified into five classes as previously mentioned:(18)

Class I: Normal,

Class II: Teeth with prosthetic crown,

Class III: Teeth with root canal therapy,

Class IV: Teeth with both root canal therapy and crown,

Class V: Teeth with severe carries that proceed more than half of dentin.

\section{Statistical analysis}

SPSS 23.0 (SPSS Inc., Chicago, IL, USA) was used for statistical analyses. The effect of age and gender on the association between root apices of posterior teeth and sinus floor was investigated. Age was recorded into three categorie. Due to the reponse variable and the covariates are categorical, Chisquare test was applied to analyze the relationship between root apices of maxillary premolars/molars and sinus floor by gender, age and in sinuses. $\mathrm{P}$ values $<0.05$ were considered sufficient to indicate statistical significance. 


\section{Results}

Based on current results; 1127 root apices were not in contact with the maxillary sinus floor, and 731 teeth root apices were in contact with the sinus. 135 buccal root apices were penetrated into the sinus cavity where 70 palatal root apices were also penetrated. 9 buccal and palatal root apices were also inside the sinus cavity (Table 1).

According to the findings of this study, class I was most frequently seen in the second premolar teeth and first molar teeth. Class II was the most frequently seen in the second molar teeth and class I was the most frequently seen in the third molar teeth (Table 1). No significant association were detect between the left and right regions, and as well as the relationship between premolars/molars to maxillary sinus $(P=0.082)$. There was only significant association between gender and first molars ( $P=0.036)$ (Figure 2$)$. Age is an important factor in the relationship of the root of teeth with the sinus ( $P=0.037$ ) (Figure 3 ).

When the pulpoapical condition was assessed, 289 teeth had prosthetic crown, 212 teeth had root canal therapy, 39 teeth received both root canal therapy and crown, and 45 teeth had severe carries that proceed more than half of dentin. There was no significant difference between pulpoapical condition of teeth and gender both left and right side $(P=0.065, P=0.072)$ (Figure 4). Further, no associations were detected between pulpoapical condition of teeth and left/ right sinus sides $(P=0.081)$. However, there were significant associations between pulpoapical condition of teeth and age $(P=0.023)$ (Figure 5$)$. Table 2 shows pulpoapical conditions of premolars/molars.

\section{Discussion}

In the present study, we investigated pulpoapical condition of maxillary premolar/molar teeth and the association between the root of these teeth and the sinus floor. The main structure that should be considered in surgical/nonsurgical procedures in the upper jaw posterior region is the maxillary sinus $(19,20)$. Due to the close proximity between posteriors and the maxillary sinus, microorganisms in apical lesions may pass by possibly infiltrating through porosity of bone (21). The roots of the maxillary posteriors are in close proximity to the sinus, in some cases even less than $1 \mathrm{~mm}$ that may, cause sinus perforation frequently during dental procedures $(19,20)$. Previous studies reported that the perforation rate was between $10 \%$ and $50 \%(22,23)$. Before apicoectomies, the distance between the posterior roots and the sinus floor presented to be considered very important and should be carefully evaluated to prevent possible complications (24).

According to the result of this study, we detected that Class I (77.7\%) was the most frequently seen and Class V $(0.2 \%)$

Table 1. The vertical relationship between root of the maxillary premolars/molars and the sinus floor

\begin{tabular}{|c|c|c|c|c|c|c|}
\hline & Class I & Class II & Class III & Class IV & Class V & Total \\
\hline \multicolumn{7}{|l|}{ Right } \\
\hline 2nd premolars & 238 (39.5\%) & $59(9.8 \%)$ & $7(1.20 \%)$ & $1(0.2)$ & $0(0 \%)$ & 305 (50.7\%) \\
\hline 1st molars & $119(23.8 \%)$ & $100(20.0 \%)$ & $18(3.6 \%)$ & 17 (3.4\%) & $2(0.4 \%)$ & 256 (51.2\%) \\
\hline 2nd molars & 127 (20.4\%) & $117(18.8 \%)$ & 43 (6.9\%) & $17(2.7 \%)$ & $0(0 \%)$ & 304 (48.8\%) \\
\hline 3rd molars & $103(29.7 \%)$ & 57 (16.4\%) & $10(2.9 \%)$ & $1(0.3 \%)$ & $0(0 \%)$ & 171 (49.3\%) \\
\hline
\end{tabular}

\section{Left}

\begin{tabular}{cccccccc}
\hline 2nd premolars & $230(38.2 \%)$ & $58(9.6 \%)$ & $6(1 \%)$ & $2(0.2 \%)$ & $1(0.2 \%)$ & $297(49.3 \%)$ \\
\hline 1st molars & $108(21.6 \%)$ & $94(18.8 \%)$ & $23(4.6 \%)$ & $18(3.6 \%)$ & $1(0.2 \%)$ & $244(48.8 \%)$ \\
\hline 2nd molars & $102(16.4 \%)$ & $178(28.6 \%)$ & $26(4.2 \%)$ & $10(1.6 \%)$ & $3(0.5 \%)$ & $319(51.2 \%)$ \\
\hline Total & 3rd molars & $100(28.8 \%)$ & $68(19.6 \%)$ & $2(0.6 \%)$ & $4(1.2 \%)$ & $2(0.6 \%)$ & $176(50.7 \%)$ \\
\hline
\end{tabular}

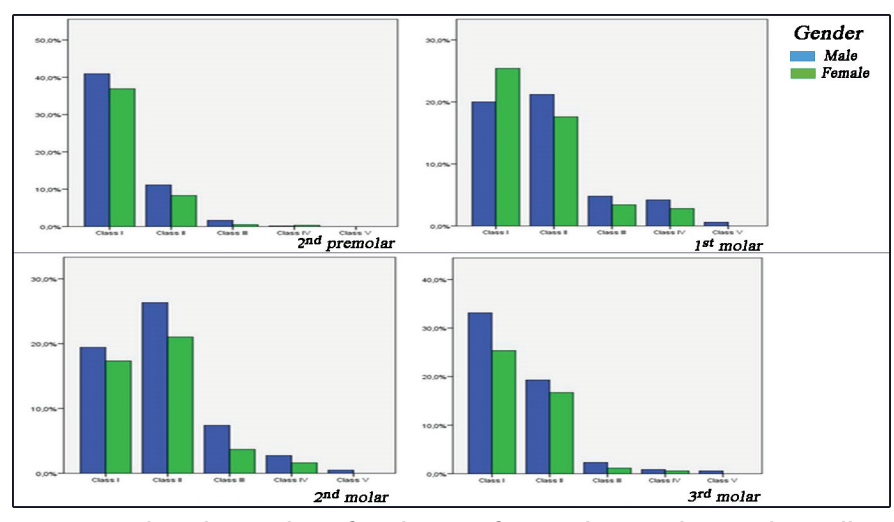

Figure 2. The relationship of each root of premolars/molars and maxillary sinus and gender.

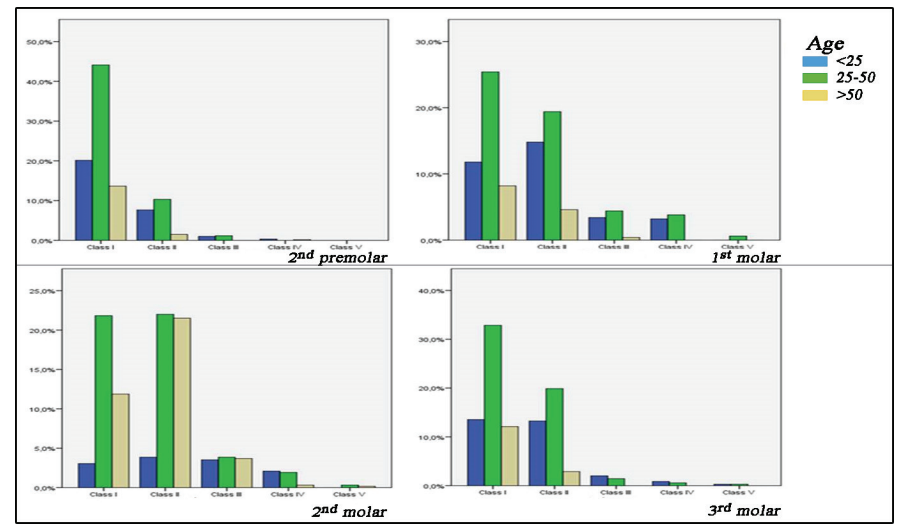

Figure 3. The relationship of each root of premolars/molars and maxillary sinus and age. 


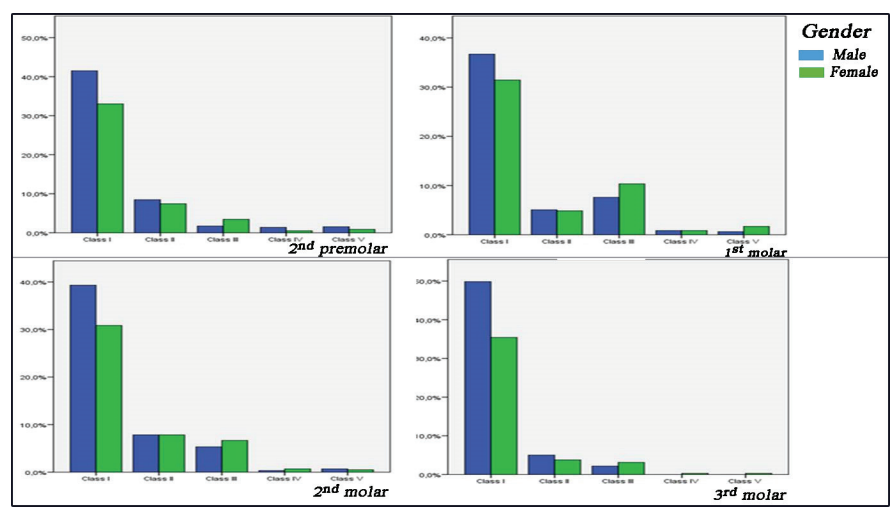

Figure 4. The relationship between pulpoapical condition of teeth and gender.

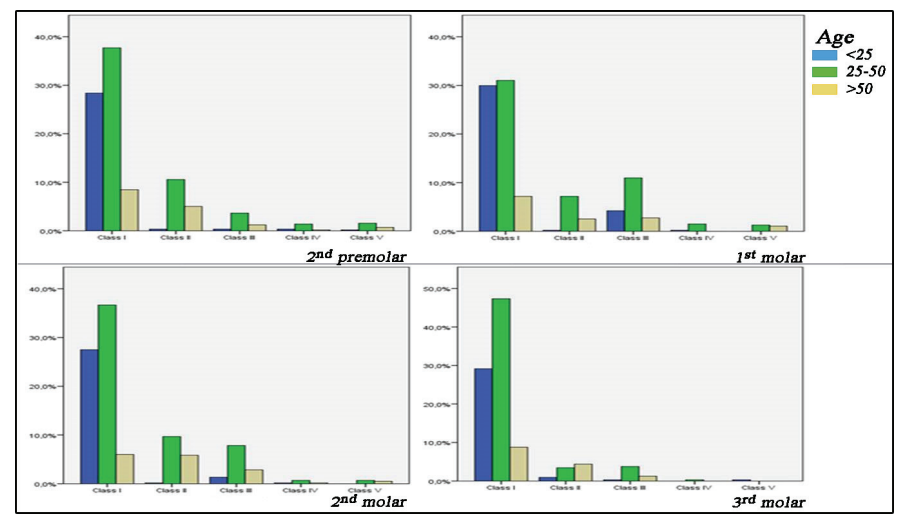

Figure 5. The relationship between pulpoapical condition of teeth and

Table 2. The pulpoapical candition maxillary premolars/molars

\begin{tabular}{cccccccc}
\hline \multicolumn{1}{c}{ Right } & Class I & Class II & Class III & Class IV & Class V & Total \\
\hline 2nd premolars & $228(37.8 \%)$ & $49(8.1 \%)$ & $16(2.6 \%)$ & $6(0.9 \%)$ & $6(0.9 \%)$ & 305 \\
\hline 1st molars & $170(34 \%)$ & $33(6.6 \%)$ & $43(8.6 \%)$ & $5(1 \%)$ & $5(1 \%)$ & 256 & $4(0.4 \%)$ \\
\hline 2nd molars & $220(35.3 \%)$ & $41(6.5 \%)$ & $36(5.7 \%)$ & $3(0.4 \%)$ & 304 \\
\hline 3rd molars & $140(40.3 \%)$ & $15(4.3 \%)$ & $10(2.8 \%)$ & $3(0.8 \%)$ & $3(0.8 \%)$ & 171 \\
\hline
\end{tabular}

Left

\begin{tabular}{cccccccc}
\hline 2nd premolars & $215(35.7 \%)$ & $49(8.1 \%)$ & $17(2.8 \%)$ & $7(1.1 \%)$ & $9(1.4 \%)$ & 297 \\
\hline 1st molars & $161(32.2 \%)$ & $25(5 \%)$ & $43(8.6 \%)$ & $6(1.2 \%)$ & $9(1.8 \%)$ & 244 \\
\hline 2nd molars & $210(33.7 \%)$ & $59(9.4 \%)$ & $38(6.0 \%)$ & $6(0.9 \%)$ & $6(0.9 \%)$ & 319 \\
\hline Total & 3rd molars & $143(41.2 \%)$ & $18(5.1 \%)$ & $9(2.5 \%)$ & $3(0.8 \%)$ & $3(0.8 \%)$ & 176 \\
\hline
\end{tabular}

was the least frequently detected in the second premolar teeth. Kwak et al. demonstrated that the roots of the premolars are in close proximity to the sinus floor when compared to those of the molars. The present study reported here are in support of their findings (18). The clinicians should consider these findings before planning root canal treatment and apical surgery procedures. Further, there were no significant association between the left and right region of the second premolar teeth, this result is also similar to of Kilic el al. (5) As well as second premolar were evaluated by gender, on contrary to the results of the research by Ok et al. (2), we suggest that some differences were detect in the second premolar: Class I and Class II were more common in males, however Class III was more common in females. Similar to our study, Kilic et al. reported that there was no significant association according to gender (5). The pulpoapical evaluation revealed that the Class I was the most frequently and Class IV was the least diagnosed. No statistically significant difference was obtained between pulpoapical condition and gender $(P=0.07)$. The findings of the present study showed that age was an important factor on the relationship of teeth to the sinus and on the pulpoapical condition $(P=0.023)$.

Previous studies have searched for the interaction between the molar roots and the sinus $(3,25)$. Wallace et al. detected that the roots of the first and second molars were closely related to maxillary sinus in $40 \%$ of cases (25). Class I was the most frequently seen in first and third molars, 45.4\%, 58.5\% respectively, whereas Class II was the (47.4\%) most frequently seen in second molars. Class $\mathrm{V}$ was the least frequently seen in all molar teeth. Similar to our results, most studies detected that roots of second molars were closely associated with the maxillary sinus floor $(3,26,27)$. The relationship between buccal and palatal roots and sinus floor were found difference. The present study showed that buccal root apices were frequently projecting into the sinus cavity than palatal roots in first, second and third molars. In contrast with this study, Ok et al. suggested that the palatal roots were frequently penetrated into the sinus (2). Whereas similar to the buccal roots of the first molars were often penetrated into the sinus floor. In accordance with this study, Eberhardt et al. detected that the buccal roots of the second molars were the extended to the sinus (27). Jung et al. observed that intrusion of the roots into the sinus floor was frequently buccal roots of the molars, where second molars were the closest to the sinus floor (10). We might suggest that the roots of the second molars are closest to the sinus which is similar to the results of Kwak et al (18). When published evidence is considered having different methods, age groups and race may be causing these differences. The present study detected significant associations between the relation of each root and maxillary sinus and age $(P<0.05)$. Differences between the age groups may be associated with the development of sinus and roots of teeth may change over time. There was a significant association between vertical dimensions of teeth 
with sinus and right/left sides in second and third molars. The only significant difference was detected between gender and the relationship of each root with maxillary sinus in first molars.

When pulpoapical condition was evaluated, Class I was the most frequent, and Class IV and Class V had the lowest in all teeth ( $2^{\text {nd }}$ premolar, $1^{\text {st }}, 2^{\text {nd }}$ and $3^{\text {rd }}$ molars). Age is an imported factor for pulpoapical conditions. According to the present findings, there was a significant difference between age and pulpoapical conditation $(P=0.023)$. With age, most people have odontogenic problems which may result with missing teeth, periodontal disease, endodontic problems, prosthodontic procedures, dental caries, apical abscess, and other pathologic conditions $(28,29)$.

When the limitation of the present study is considered, the distance between each individual root of posterior maxillary teeth was not measured.

\section{Conclusion}

Second molar teeth are the most closest to the maxillary sinus. For pulpoapical condition, Class I is the most commonly seen in all evaluated teeth. Age is affected by both the pulpoapical condition and the relationship between the roots of molars/premolars to maxillary sinus floor. CBCT analysis is a very important tool to evaluate maxillary premolars/molars before dental procedure to prevent accidental oroantral complications such as sinus membrane perforation, penetration of foreign bodies and the possible risk of an infectious disease within the sinus.

Ethics Committee Approval: Ethics Committee approval was obtained from the Institutional Ethics Committee of the Firat University. All patients approved to this study.

Informed Consent: Participants provided informed constent.

Peer-review: Externally peer-reviewed.

Author contributions: TTY and MDT designed the study. TTY participated in generating the data for the study FO and MDT participated in gathering the data for the study. FO and MDT participated in the analysis of the data. TTY wrote the majority of the original draft of the paper. TTY and MDT participated in writing the paper. All authors approved the final version of this paper.

Conflict of Interest: Authors declared no conflict of interest.

Financial Disclosure: The authors declared that they have received no financial support.

Acknowledgments: The authors would like to thank Associate Professor Tolga Fikret Tözüm for critically revised the manuscript

Türkçe Özet: Maksiller Sinus ile Posterior Dişlerin Kökleri Arasındaki Topografik IIlişki: Konik Işınlı Bilgisayarlı Tomografi Analiz. Amaç: Bu çalışmanın amacı, Konik Işınlı Bilgisayarlı Tomografi (KIBT) kullanarak kök uçları ile maksiller sinüs duvarı arasındaki ilişkiyi ve 2. küçük azı, 1. azı, 2. azı ve 3. azı dişlerinin pulpoapikal durumunu analiz etmektir. Gereç ve Yöntemler: Bu çalışmada, oral diagnoz ve radyoloji bölümüne başvuran 500 kişiye ait 1000 maksiller sinüs KIBT görüntüleri retrospektif bir şekilde analiz edildi. Her diş kökünün sinüs tabanı ile ilişkisi ve pulpoapikal durumu değerlendirilerek kategorize edildi. Cinsiyet, yaş ve sağ/sol taraf arasındaki ilişki değerlendirildi. Bulgular: Toplam 602 ikinci premolar, 500 birinci molar, 623 ikinci molar, 347 üçüncü molar diş değerlendirildi. Dişlerin pulpoapikal durumu ile cinsiyet veya sol ve sağ taraf arasında anlamlı fark yoktur $(P=0.065, P=0.072)$. Tüm dişlerin pulpoapikal durumu ile yaş arasında $(P=0.023)$ ve köklerin maksiller sinüs ilişkisi ile yaş arasında $(P=0.037)$ istatistiksel olarak anlamlı farklılık vardır. Ikinci ve üçüncü büyük azı dişlerin vertikal pozisyonu ile sağ / sol taraf arasında anlamlı ilişki vardır $(P=0.033)$. Sonuç: Yaşın, dişlerin periapikal durumu ve diş köklerinin maksiller sinüs ile ilişkisi üzerinde etkili bir parametre olduğu görülmektedir. Anahtar Kelimeler: Radyoloji, yaş, inflamasyon, pulpa, kök kanalı

\section{References}

1. Goller-Bulut D, Sekerci AE, Kose E, Sisman Y. Cone beam computed tomographic analysis of maxillary premolars and molars to detect the relationship between periapical and marginal bone loss and mucosal thickness of maxillary sinus. Med Oral Patol Oral Cir Bucal 2015;20:e572-9. [CrossRef]

2. Ok E, Gungor E, Colak M, Altunsoy M, Nur BG, Aglarci OS. Evaluation of the relationship between the maxillary posterior teeth and the sinus floor using cone-beam computed tomography. Surg Radiol Anat 2014;36:907-14. [CrossRef]

3. Hauman $\mathrm{CH}$, Chandler NP, Tong DC. Endodontic implications of the maxillary sinus: a review. Int Endod J 2002;35:127-41. [CrossRef]

4. Sharan A, Madjar D. Correlation between maxillary sinus floor topography and related root position of posterior teeth using panoramic and cross-sectional computed tomography imaging. Oral Surg Oral Med Oral Pathol Oral Radiol Endod 2006;102:37581. [CrossRef]

5. Kilic C, Kamburoglu K, Yuksel SP, Ozen T. An Assessment of the Relationship between the Maxillary Sinus Floor and the Maxillary Posterior Teeth Root Tips Using Dental Cone-beam Computerized Tomography. Eur J Dent 2010;4:462-7. [CrossRef]

6. Ezzodini Ardakani F, Razavi SH, Tabrizizadeh M. Diagnostic value of cone-beam computed tomography and periapical radiography in detection of vertical root fracture. Iran Endod J 2015;10:122-6.

7. Watzek G, Bernhart T, UIm C. Complications of sinus perforations and their management in endodontics. Dent Clin North Am 1997;41:563-83.

8. Engstrom H, Chamberlain D, Kiger R, Egelberg J. Radiographic evaluation of the effect of initial periodontal therapy on thickness of the maxillary sinus mucosa. J Periodontol 1988;59:604-8. [CrossRef]

9. Ariji Y, Obayashi N, Goto M, Izumi M, Naitoh M, Kurita K, et al. Roots of the maxillary first and second molars in horizontal relation to alveolar cortical plates and maxillary sinus: computed tomography assessment for infection spread. Clin Oral Investig 2006;10:35-41. [CrossRef]

10. Jung $\mathrm{YH}, \mathrm{Cho} \mathrm{BH}$. Assessment of the relationship between the maxillary molars and adjacent structures using cone beam computed tomography. Imaging Sci Dent 2012;42:219-24. [CrossRef]

11. Fuhrmann R, Bucker A, Diedrich P. Radiological assessment of artificial bone defects in the floor of the maxillary sinus. Dentomaxillofac Radiol 1997;26:112-6. [CrossRef]

12. Wehrbein $H$, Diedrich P. [The initial morphological state in the basally pneumatized maxillary sinus--a radiological-histological study in man]. Fortschr Kieferorthop 1992;53:254-62. [CrossRef]

13. Savolainen S, Eskelin $M$, Jousimies-Somer $H$, Ylikoski J. Radiological findings in the maxillary sinuses of symptomless young men. Acta Otolaryngol Suppl 1997;529:153-7. [CrossRef]

14. Lu Y, Liu Z, Zhang L, Zhou X, Zheng Q, Duan X, et al. Associations between maxillary sinus mucosal thickening and apical periodontitis using cone-beam computed tomography scanning: a retrospective study. J Endod 2012;38:1069-74. [CrossRef]

15. Ludlow JB, Ivanovic M. Comparative dosimetry of dental CBCT devices and 64-slice CT for oral and maxillofacial radiology. Oral Surg Oral Med Oral Pathol Oral Radiol Endod 2008;106:106-14. [CrossRef] 
16. Guncu GN, Yildirim YD, Wang HL, Tozum TF. Location of posterior superior alveolar artery and evaluation of maxillary sinus anatomy with computerized tomography: a clinical study. Clin Oral Implants Res 2011;22:1164-7. [CrossRef]

17. Sheikhi M, Pozve NJ, Khorrami L. Using cone beam computed tomography to detect the relationship between the periodontal bone loss and mucosal thickening of the maxillary sinus. Dent Res J (Isfahan) 2014;11:495-501.

18. Kwak HH, Park HD, Yoon HR, Kang MK, Koh KS, Kim HJ. Topographic anatomy of the inferior wall of the maxillary sinus in Koreans. Int J Oral Maxillofac Surg 2004;33:382-8. [CrossRef]

19. Tian XM, Qian L, Xin XZ, Wei B, Gong Y. An Analysis of the Proximity of Maxillary Posterior Teeth to the Maxillary Sinus Using Cone-beam Computed Tomography. J Endod 2016;42:371-7. [CrossRef]

20. Kang SH, Kim BS, Kim Y. Proximity of Posterior Teeth to the Maxillary Sinus and Buccal Bone Thickness: A Biometric Assessment Using Cone-beam Computed Tomography. J Endod 2015;41:1839-46. [CrossRef]

21. Phothikhun S, Suphanantachat S, Chuenchompoonut V, Nisapakultorn K. Cone-beam computed tomographic evidence of the association between periodontal bone loss and mucosal thickening of the maxillary sinus. J Periodontol 2012;83:557-64. [CrossRef]

22. Rud J, Rud V. Surgical endodontics of upper molars: relation to the maxillary sinus and operation in acute state of infection. $J$ Endod 1998;24:260-1. [CrossRef]
23. Freedman A, Horowitz I. Complications after apicoectomy in maxillary premolar and molar teeth. Int J Oral Maxillofac Surg 1999;28:192-4. [CrossRef]

24. Khongkhunthian P, Reichart PA. Aspergillosis of the maxillary sinus as a complication of overfilling root canal material into the sinus: report of two cases. J Endod 2001;27:476-8. [CrossRef]

25. Wallace JA. Transantral endodontic surgery. Oral Surg Oral Med Oral Pathol Oral Radiol Endod 1996;82:80-3. [CrossRef]

26. Georgescu CE, Rusu MC, Sandulescu M, Enache AM, Didilescu AC. Quantitative and qualitative bone analysis in the maxillary lateral region. Surg Radiol Anat 2012;34:551-8. [CrossRef]

27. Eberhardt JA, Torabinejad M, Christiansen EL. A computed tomographic study of the distances between the maxillary sinus floor and the apices of the maxillary posterior teeth. Oral Surg Oral Med Oral Pathol 1992;73:345-6. [CrossRef]

28. Tozum TF, Guncu GN, Yildirim YD, Yilmaz HG, Galindo-Moreno $P$, Velasco-Torres $M$, et al. Evaluation of maxillary incisive canal characteristics related to dental implant treatment with computerized tomography: a clinical multicenter study. J Periodontol 2012;83:337-43. [CrossRef]

29. Vallo J, Suominen-Taipale L, Huumonen S, Soikkonen K, Norblad A. Prevalence of mucosal abnormalities of the maxillary sinus and their relationship to dental disease in panoramic radiography: results from the Health 2000 Health Examination Survey. Oral Surg Oral Med Oral Pathol Oral Radiol Endod 2010;109:e80-7. [CrossRef] 